\title{
MENINGKATKAN PEMAHAMAN MATERI GLOBALISASI DAN SIKAP SOSIAL SISWA MELALUI MODEL PEMBELAJARAN KOOPERATIF GROUP INVESTIGATION DI KELAS IV MADRASAH IBTIDAIYAH NURUL HUDA CIMANGGIS DEPOK
}

\author{
Sri Rahayu Pudjiastuti ${ }^{a^{*}}$ \\ a) STKIP Arrahmaniyah, Depok, Indonesia \\ *)e-mail korespondensi : yayu.pudjiastuti@gmail.com
}

\begin{abstract}
Abstrak. Rendahnya sikap sosial siswa yang ditandai oleh kurangnya kepedulian sosial siswa dengan teman, kurang peka terhadap lingkungan, kurangnya sosialisasi dan komunikasi antar siswa, serta siswa kurang aktif dalam mengikuti pembelajaran dan rendahnya hasil belajar PKn,hal ini dibuktikan dengan rendahnya perolehan nilai hasil belajar siswa pada konsep globalisasi, atas dasar hal tersebut diperlukan penerapan model pembelajaran untuk mengatasi permasalahan tersebut. model pembelajaran yang tepat adalah group investigation model ini dipilih karena di dalamnya mengandung kegiatan-kegiatan yang menarik serta mengarahkan siswa untuk lebih aktif berpartisipasi dalam proses pembelajaran dan mendorong kreativitas siswa untuk berkompetisi dengan teman sebayanya, melatih bekerjasama dalam sebuah tim serta mengembangkan sikap siswa. Metode penelitian ini menggunakan metode penelitian tindakan kelas (PTK). Jumlah responden 40 orang, instrumen yang digunakan adalah tes untuk mengukur pemahaman materi globalisasi dan observasi untuk mengamati sikap sosial dan aktivitas siswa dalam melakukan group investigation. Hasil penelitian menunjukkan: (1) Dari hasil observasi terhadap kegiatan pembelajaran yang dilakukan peneliti yaitu siklus pertama $65 \%$, siklus kedua $75 \%$, dan siklus ketiga 85\%. (2) Aktivitas siswa sangat baik, sesuai dengan persentase hasil observasi terhadap aktivitas siswa dalam kegiatan belajar mengajar yaitu siklus pertama 65\%, siklus kedua 75\%, dan siklus ketiga 85\%. 3) Sikap sosial siswa pun terjadi peningkatan. Siklus I menunjukan persentase sikap sosial siswa sebesar $68 \%$ dengan kategori cukup, meningkat pada siklus II menjadi $81 \%$ dengan kategori baik, meningkat kembali pada siklus III menjadi 89\% dengan kategori sangat baik.
\end{abstract}

Kata Kunci: Globalisasi; sikap sosial; group investigation.

IMPROVING THE UNDERSTANDING OF GLOBALIZATION MATERIALS AND STUDENTS 'SOCIAL ATTITUDE THROUGH COOPERATIVE GROUP INVESTIGATION LEARNING MODELS IN CLASS IV, MADRASAH IBTIDAIYAH NURUL HUDA, DEPOK.

Abstract. The low social attitudes of students are characterized by a lack of social awareness of students with friends, lack of sensitivity to the environment, lack of socialization and communication between students, as well as students being less active in participating in learning and low learning outcomes of Civics, this is evidenced by the low acquisition of student learning outcomes in the concept of globalization, based on this the application of learning models is needed to overcome these problems. the right learning model is that the group investigation model was chosen because it contains interesting activities and directs students to more actively participate in the learning process and encourages students' creativity to compete with their peers, trains to work together in a team and develops student attitudes. This research method uses classroom action research. The number of respondents was 40 student, the instrument used was a test to measure understanding of globalization material and observation to observe social attitudes and student activities in conducting group investigations. The results showed: (1) From the results of observations on learning activities carried out by researchers, namely the first cycle $65 \%$, the second cycle $75 \%$, and the third cycle $85 \%$. (2) Student activities are very good, according to the percentage of observations on student activities in teaching and learning activities, namely the first cycle $65 \%$, the second cycle 75\%, and the third cycle $85 \%$. 3) Social attitudes of students also increase. Cycle I shows the percentage of students' social attitudes of $68 \%$ with enough categories, increased in cycle II to $81 \%$ with good categories, increased again in cycle III to $89 \%$ with very good categories

Keywords: Globalization; social attitude; group investigation.

\section{PENDAHULUAN}

Pembelajaran PKn diharapkan mampu membentuk siswa menjadi aktif, memiliki sikap yang baik, saling menghargai dan menjadi warga negara yang baik dalam kehidupan sosialnya di masyarakat. Siswa akan mudah berinteraksi dengan orang lain, diterima dalam masyarakat dan dapat mengambil keputusan ketika menghadapi masalah dalam kehidupannya. Siswa juga dapat mengenal tentang hubungan antara manusia dengan lingkungan hidupnya, memahami peristiwa-peristiwa serta perubahan-perubahan yang terjadi disekitarnya, memahami bahwa antara manusia yang satu dengan manusia yang lain saling membutuhkan, saling menghormati, dan memiliki rasa tanggung jawab terhadap kewajibannya.

Sikap sosial sangat dibutuhkan untuk menjalin hubungan dengan orang lain dalam kehidupan sehari-hari. Abu Ahmadi menyebutkan bahwa sikap sosial adalah kesadaran individu yang menentukan perbuatan nyata dan 
berulang-ulang terhadap obyek sosial. Sikap sosial ini tidak dinyatakan oleh seorang tetapi diperhatikan oleh orangorang sekelompoknya (Ahmadi [1]). Budaya sekolah dapat diidentifikasikan dari setiap lapisan budaya sekolah yang terbagi dua yaitu lapisan yang dapat diamati dan lapisan yang tersembunyi atau lapisan yang tidak dapat diamati [2]

Sikap sosial merupakan suatu tindakan seseorang untuk hidup dalam masyarakatnya seperti saling membantu, saling menghormati, saling berinteraksi, dan sebagainya. Sikap sosial perlu dikembangkan karena dapat menciptakan suasana hidup yang damai, rukun, nyaman, dan tentram. Sikap sosial merupakan tindakan yang dapat mengatasi berbagai masalah yang ada dalam masyarakat dengan berpikir secara bersama-sama. Siswa mulai mengenal dan menjalin interaksi satu sama lain di sekolah, sehingga siswa mulai berteman dengan siswa yang lain, dalam berteman siswa memilih teman yang disukai, siswa akan percaya diri apabila memiliki banyak teman yang sesuai dengan pilihannya. Siswa akan membentuk seperti kelompok atau gang dalam bermain dan menjauhi siswa yang tidak disukai sehingga kurang terjadi interaksi yang menyebabkan rasa saling membenci dan tidak peduli dengan siswa yang lain. Sikap sosial menunjuk pada predisposisi, sikap (kecenderungan berbuat atau tidak berbuat dalam situasi tersedia) yang dimiliki bersama dengan sejumlah orangorang lain yang sama keyakinan, nilai-nilai, ideologi atau orientasi politik (Mappiare [3]).

Hurlock mengatakan bahwa perkembangan sosial berarti perolehan kemampuan berperilaku yang sesuai dengan tuntunan sosial. Untuk menjadi orang yang mampu bermasyarakat, memerlukan tiga proses. Masing-masing proses terpisah dan sangat berbeda satu sama lain namun saling berkaitan, sehingga kegagalan dalam satu proses akan menurunkan kadar sosialisasi individu (Hurlock [4]).

Rendahnya sikap sosial siswa terlihat dari pengamatan lapangan ketika observasi di Madrasah Ibtidaiyah Nurul Huda Cimanggis Depok kelas IV yaitu kurangnya kepedulian sosial siswa dengan teman, kurang peka terhadap lingkungan, kurangnya sosialisasi dan komunikasi antar siswa. Selain itu,masih banyak siswa yang saling bermusuhan dengan siswa lain, tidak mengetahui ada teman yang sedang sakit atau tidak berangkat sekolah, tidak meminjamkan pensil kepada teman yang tidak membawa, sulit menyesuaikan diri dengan teman, ingin menang sendiri, saling berebut ketika sedang bermain, dan dalam berteman masih suka memilih-milih sehingga ketika bermain hanya bersama gang/kelompoknya. Pada proses pembelajaran berlangsung mereka masih saling mengejek dan menertawakan jika ada siswa yang tidak dapat menjawab pertanyaan guru.

Hasil observasi dan wawancara dengan guru menemukan data bahwa nilai ulangan harian selalu rendah. Dalam upaya pengembangan sikap sosial siswa ini maka peneliti memilih mata pelajaran PKN, meskipun bukan berarti apabila nilai PKN siswa rendah maka sikap sosialnya juga rendah atau sebaliknya. Mata pelajaran PKN sangat penting dalam kehidupan sehari-hari untuk membentuk sikap dan hubungan yang baik dengan sesamanya, mengetahui sejarah bangsa, menghargai para pahlawan, dan mampu menghadapi masalah sosial yang dihadapinya.

Guru melakukan proses pembelajaran PKN kurang menggali potensi yang dimiliki siswa. Metode yang tidak divariasikan kurang efektif untuk digunakan dalam proses pembelajaran karena menyebabkan siswa pasif. Pembelajaran PKN sulit ditangkap siswa karena cenderung menghafal dan kurangnya ketersediaan media pembelajaran yang mendukung. Penggunaan media pembelajaran yang jarang dilakukan juga menjadi penyebab belum berhasilnnya proses pembelajaran yang berlangsung. Siswa merasa bosan karena pembelajaran yang dilakukan guru monoton.

Guru lebih menekankan nilai kognitif saat menyampaikan materi pembelajaran di kelas, sedangkan nilai afektif dan psikomotor kurang diperhatikan.Proses pembelajaran yang berlangsung di kelas masih terpusat pada guru dan kurang melibatkan siswa. Siswa datang ke sekolah hanya duduk dan diam mendengarkan guru, belum berani untuk bertanya dan mengemukakan pendapatnya tentang materi yang dipelajari, sehingga interaksi antarsiswa dan pengembangan sikap sosial siswa masih kurang diperhatikan ketika proses pembelajaran. Proses pembelajaran tersebut membuat siswa kurang aktif dan bersosialisasi dengan teman sebayanya, padahal sesuai karakteristik usia siswa sekolah dasar, berinteraksi dengan lingkungannya sangat penting karena dapat membentuk suatu sikap sosial siswa terhadap sekitarnya.

Siswa dalam berteman sering membentuk suatu kelompok, ketika istirahat siswa bermain dengan kelompoknya, tidak bermain dengan siswa yang lain karena kurang saling mengenal dekat dan jarang terjadi interaksi dengan siswa satu kelas ketika proses pembelajaran, sehingga membuat siswa kurang peka dan peduli terhadap lingkungan sekitarnya. Pada akhirnya dapat berpengaruh pada rendahnya sikap sosial siswa dalam proses pembelajaran maupun di luar proses pembelajaran. Pemahaman konsep dan Keterampilan Proses meningkat setelah siswa mengalami proses pembelajaran tugas kelompok [5].

Dari beberapa poin di atas sangat jelas bahwa permasalahan pembelajaran PKn di MI Nurul Huda Kampung Rumbut Cimanggis Depok khususnya kelas IV adalah rendahnya sikap sosial siswa yang ditandai oleh kurangnya kepedulian sosial siswa dengan teman, kurang peka terhadap lingkungan, kurangnya sosialisasi dan komunikasi antar siswa, serta siswa kurang aktif dalam mengikuti pembelajaran dan rendahnya hasil belajar PKn,hal ini dibuktikan dengan rendahnya perolehan nilai hasil belajar siswa pada konsep globalisasi. Dari 40 siswa Kelas IV MI Nurul Huda Cimanggis Depok hanya 18 siswa atau 20\% saja yang mampu memperoleh nilai di atas rata-rata KKM yang telah ditetapkan sebesar 75, sisanya 32 siswa atau setara dengan $80 \%$ masih sangat jauh dari ketercapaian ketuntasan yang diharapkan.

Berdasarkan data di atas guru perlu melakukan tindakan perbaikan pembelajaran menuju pembelajaran yang lebih berkualitas di mana kemampuan berpikir siswa dilatih 
secara terus menerus dengan menggunakan model pembelajaran yang sesuai dengan perkembangan mental siswa. Salah satu model pembelajaran yang tepat adalah group investigation dapat dipilih karena di dalamnya mengandung kegiatan-kegiatan yang menarik serta mengarahkan siswa untuk lebih aktif berpartisipasi dalam proses pembelajaran dan mendorong kreativitas siswa untuk berkompetisi dengan teman sebayanya, melatih bekerja sama dalam sebuah tim serta mengembangkan sikap siswa. Model pembelajaran kooperatif tipe group investigation merupakan salah satu tipe dari model pembelajaran kooperatif yang berupa kegiatan belajar yang memfasilitasi siswa untuk belajar dalam kelompok kecil yang heterogen, dimana siswa yang berkemampuan tinggi bergabung dengan siswa yang berkemampuan rendah untuk belajar bersama dan menyelesaikan suatu masalah yang ditugaskan oleh guru kepada siswa."Implementasi dari model group investigation sangat tergantung dari pelatihan awal dalam penguasaan keterampilan komunikasi dan sosial"(Rusman [6]). Menurut Huda [7] Group Investigation diklasifikasikan sebagai metode investigasi kelompok karena tugas-tugas yang diberikan sangat beragam, mendorong siswa untuk mengumpulkan dan mengevaluasi informasi dari beragam sumber, komunikasinya bersifat bilateral.

Group Investigation merupakan salah satu tipe kompleks dalam pembelajaran kelompok yang mengharuskan siswa untuk menggunakan skill berpikir level tinggi. Group Investigation merupakan salah satu bentuk tipe pembelajaran kooperatif yang menekankan pada partisipasi dan aktivitas siswa untuk mencari sendiri materi (informasi) pelajaran yang akan dipelajari melalui bahan-bahan yang tersedia (Riyanto [8]). Dengan penggunaan model group investigation tersebut diharapkan mampu memberikan kesempatan kepada siswa untuk berkomunikasi, kerjasama, bertukar pikiran, menjawab bahkan memberikan pertanyaan. Di samping itu juga telah dilakukan diskusi dengan guru mata pelajaran PKn terkait dengan penerapan model group investigation dalam konsep globalisasi.

\section{METODE PENELITIAN}

Penelitian ini dilaksanakan di Madrasah Ibtidaiyah Nurul Huda Cimanggis Depok. Waktu penelitian ini di mulai dari bulan Juli 2019 s/d September 2019. Metode Penelitian yang digunakan adalah penelitian tindakan kelas, yaitu menghitung seberapa jauh pengaruh antar variabel yang diteliti (Pudjiastuti [9]). Responden dalam penelitian ini adalah siswa Kelas IV MI Nurul Huda sejumlah 40 orang. Instrumen yang digunakan untuk mengukur variabel pemahaman globalisasi menggunakan tes, sedangkan untuk mendapatkan data sikap sosial siswa dan aktivitas siswa dalam penerapan model group investigation dilakukan melalui observasi. Instrumen yang standar adalah instrumen yang disusun menggunakan prosedur pengembangan instrumen yang baku dan dapat dipertanggungjawabkan tingkat validitas dan reliabilitasnya (Pudjiastuti[10]).

\section{HASIL DAN PEMBAHASAN}

Dari temuan yang diperoleh dari kegiatan belajar mengajar yang dilaksanakan 3 siklus dengan 3 kali pertemuan melalui observasi kegiatan pembelajaran, observasi aktivitas siswa dalam KBM, dan penilaian formatif tentang sikap siswa, maka dapat dinyatakan bahwa penerapan model pembelajaran Group Investigation (GI) efektif untuk digunakan pada mata pelajaran PKN materi konsep globalisasi, hal ini terlihat dari:

Kegiatan belajar mengajar pada mata pelajaran PKN materi konsep globalisasi melalui penerapan model pembelajaran Group Investigation (GI) kelas IV Madrasah Ibtidaiyah Nurul Huda Cimanggis Depok sebagaimana direncanakan guru sebelumnya berlangsung dengan baik. Hal ini dapat dilihat dari persentase hasil observasi teman sejawat terhadap kegiatan pembelajaran yang dilakukan peneliti yaitu siklus pertama $65 \%$, siklus kedua $75 \%$, dan siklus ketiga $85 \%$.

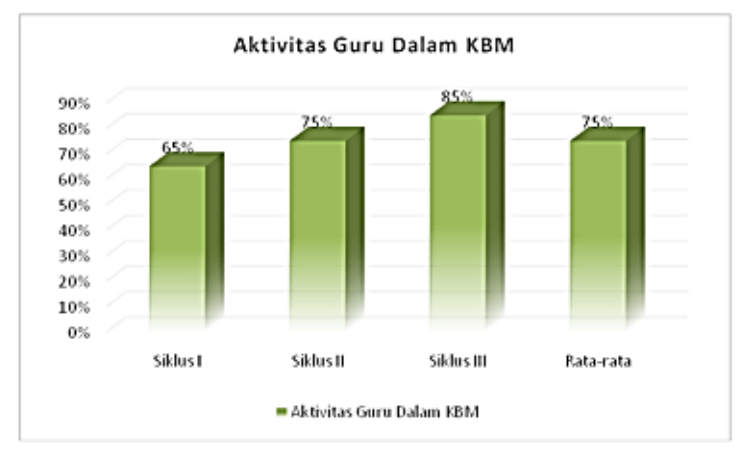

Gambar 1. Persentase Aktivitas Guru Dalam KBM

Dalam kegiatan pembelajaran mulai dari siklus pertama sampai dengan siklus ketiga terlihat aktivitas siswa sangat baik. Hal ini dilihat dari 3 kali pertemuan yang dilakukan peneliti terlihat jelas ada peningkatan aktivitas siswa dari segi partisipasi aktif siswa, kedisiplinan belajar, dan kemampuan menyimpulkan hasil belajar, sesuai dengan persentase hasil observasi teman sejawat terhadap aktivitas siswa dalam kegiatan belajar mengajar yaitu siklus pertama $65 \%$, siklus kedua $75 \%$, dan siklus ketiga $85 \%$. Rata-rata keseluruhan $75 \%$.

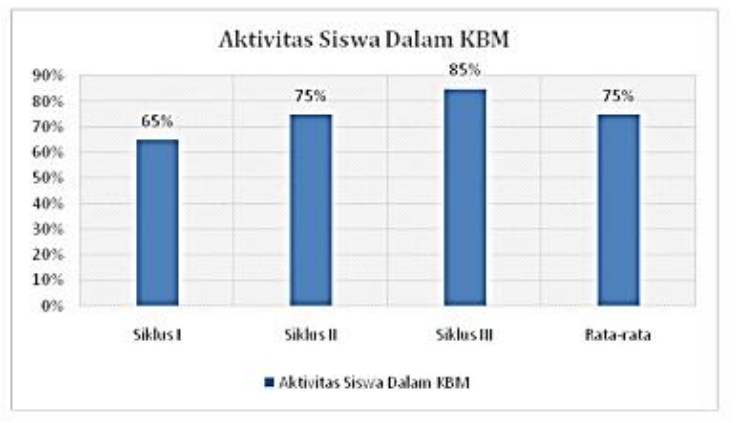

Gambar 2. Persentase Aktivitas Siswa Dalam KBM 
Tindakan kelas dengan menerapkan model pembelajaran Group Investigation (GI) pada mata pelajaran PKN materi konsep globalisasi di kelas IV Madrasah Ibtidaiyah Nurul Huda Cimanggis Depok dinyatakan berhasil dan tujuan pembelajaran yang ditetapkan tercapai. Hal ini ditunjukan dengan persentase ketuntasan hasil belajar meningkat pada tiap siklus yang dilaksanakan. Siklus I menunjukan persentase ketuntasan hasil belajar sebesar $78 \%$, meningkat pada siklus II menjadi $92 \%$, meningkat kembali pada siklus III menjadi $100 \%$.

Berdasarkan hasil observasi yang dilakukan peneliti dan teman sejawat, kemampuan sikap sosial siswa pun terjadi peningkatan. Siklus I menunjukan persentase kemampuan sikap sosial siswa sebesar $60 \%$ dengan kategori cukup, meningkat pada siklus II menjadi $78 \%$ dengan kategori baik, meningkat kembali pada siklus III menjadi $100 \%$ dengan kategori sangat baik.

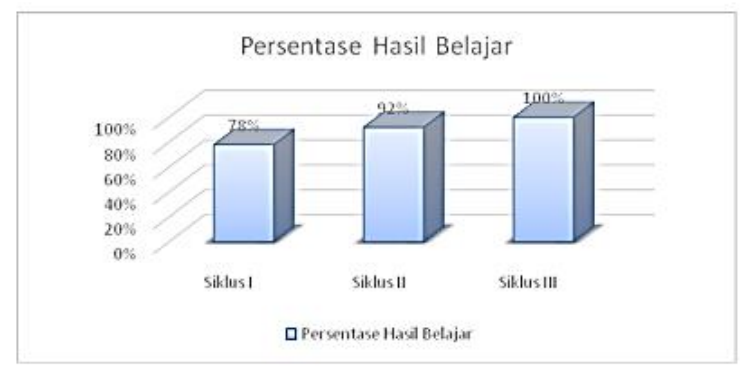

Gambar 3. Persentase Hasil Belajar Siswa

Ini artinya semua siswa telah mampu melaksanakan indikator-indikator untuk mengukur kemampuan sikap sosial dalam proses pembelajaran yang dilaksanakan.

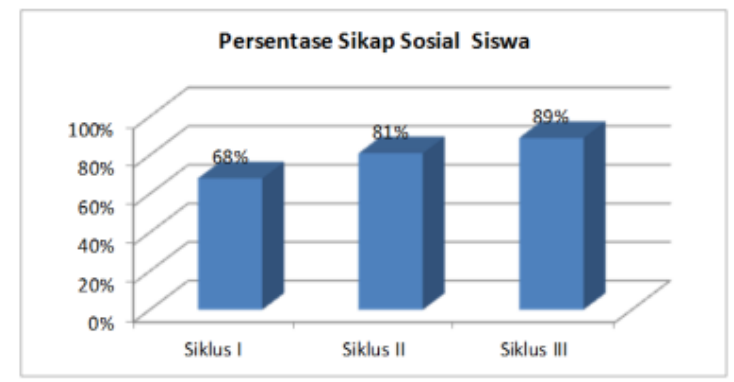

Gambar 4. Persentase Sikap sosial Siswa

Dari beberapa temuan tersebut di atas berarti pembelajaran menerapkan model Group Investigation (GI) dapat dijadikan salah satu cara untuk meningkatkan hasil belajar siswa pada mata pelajaran PKN materi konsep globalisasi karena pembelajaran ini melibatkan aktivitas aktif siswa dalam pembelajaran.

\section{SIMPULAN}

Berdasarkan pembahasan hasil penelitian, dapat disimpulkan bahwa penerapan model Group Investigation
(GI) dapat dijadikan salah satu cara untuk meningkatkan hasil belajar siswa pada mata pelajaran PKN materi konsep globalisasi karena pembelajaran ini melibatkan aktivitas aktif siswa dalam pembelajaran.Hal tersebut didasarkan pada data hasil penelitian sebagai berikut:

1. Kegiatan belajar mengajar pada mata pelajaran $\mathrm{PKN}$ materi konsep globalisasi melalui penerapan model pembelajaran Group Investigation (GI) kelas IV Madrasah Ibtidaiyah Nurul Huda Cimanggis Depok sebagaimana direncanakan guru sebelumnya berlangsung dengan baik. Hal ini dapat dilihat dari persentase hasil observasi teman sejawat terhadap kegiatan pembelajaran yang dilakukan peneliti yaitu siklus pertama $65 \%$, siklus kedua $75 \%$, dan siklus ketiga $85 \%$.

2. Dalam kegiatan pembelajaran mulai dari siklus pertama sampai dengan siklus ketiga terlihat aktivitas siswa sangat baik. Hal ini dilihat dari 3 kali pertemuan yang dilakukan peneliti terlihat jelas ada peningkatan aktivitas siswa dari segi partisipasi aktif siswa, kedisiplinan belajar, dan kemampuan menyimpulkan hasil belajar, sesuai dengan persentase hasil observasi teman sejawat terhadap aktivitas siswa dalam kegiatan belajar mengajar yaitu siklus pertama $65 \%$, siklus kedua $75 \%$, dan siklus ketiga $85 \%$.

3. Tindakan kelas dengan menerapkan model pembelajaran Group Investigation (GI) pada mata pelajaran PKN materi konsep globalisasi di kelas IV Madrasah Ibtidaiyah Nurul Huda Cimanggis Depok dinyatakan berhasil dan tujuan pembelajaran yang ditetapkan tercapai. Hal ini ditunjukan dengan persentase ketuntasan hasil belajar meningkat pada tiap siklus yang dilaksanakan. Siklus I menunjukan persentase ketuntasan hasil belajar sebesar 78\%, meningkat pada siklus II menjadi 92\%, meningkat kembali pada siklus III menjadi $100 \%$.

4. Berdasarkan hasil observasi yang dilakukan peneliti dan teman sejawat, sikap sosial siswa pun terjadi peningkatan. Siklus I menunjukan persentase sikap sosial siswa sebesar $68 \%$ dengan kategori cukup, meningkat pada siklus II menjadi $81 \%$ dengan kategori baik, meningkat kembali pada siklus III menjadi $89 \%$ dengan kategori sangat baik. Ini artinya semua siswa telah mampu melaksanakan indikator-indikator untuk mengukur sikap sosial dalam proses pembelajaran yang dilaksanakan.

\section{REFERENSI}

[1] Ahmadi, Abu. 2009. Psikologi Umum. Jakarta: Rieka Cipta. h.152

[2] R. Pertiwi and Y. Suchyadi, 2019. Implementasi Program Pendidikan Karakter Di Sekolah Dasar Negeri Lawanggintung 01 Kota Bogor, J. Pendidik. Pengajaran Guru Sekol. Dasar (JPPGuseda), vol. 02, pp. 41-46, 2019.

[3] Mappiare, A.T., Andi. 2004. Pengantar Konseling dan Psikoterapi. Jakarta: Rajawali Pers.

[4] Hurlock, Elizabeth, B. 2000. Psikologi Perkem- 
bangan. Jakarta: Erlangga. h. 7

[5] Y. Suchyadi and N. Karmila, 2019. The Application Of Assignment Learning Group Methods Through Micro Scale Practicum To Improve Elementary School Teacher Study Program College Students , Skills And Interests In Following Science Study Courses," JHSS (Journal Humanit. Soc. Stud., vol. 03, no. 02, pp. 95-98, 2019.

[6] Rusman. 2014. Model-model pembelajaran (mengembangkan profesionalisme guru). Jakarta: PT. Raja Grafindo Persada.

[7] Huda, Miftahul. 2011. Cooperative Learning. Yogyakarta: Pustaka Belajar.

[8] Riyanto, Yatim. 2010. Paradigma Baru Pembelajaran, Jakarta: Kencana

[9] Pudjiastuti, Sri Rahayu, (2017). Metodologi Penelitian Pendidikan, Depok : Fatma Aji.

[10] Pudjiastuti, Sri Rahayu. 2018. Implementation of The Mind Mapping Model With Scattergories Game in Improving Creativity and Learning Outcomes in National Education Materials. JhSS Journal of Humanities and Social Studies, e-ISSN:2598-120X | p-ISSN:2598-117X. Sinta-3. Vol.2, No.2. 